\title{
GONDOLATOK A KÖZÉPSŐ-JÓZSEFVÁROS REHABILITÁCIÓJÁNAK TÁRSADALMI ÖSSZEFÜGGÉSEIRÖL
}

\author{
(City rehabilitation in Central-Josephstadt in Budapest)
}

\section{LADÁNYI JÁNOS}

A Középsố-Józsefváros (a VIII. kerületnek a József körút és Fiumei út közötti része) a fớváros egyik legrégibb, egyre erốsebben leromló állapotú és egyre alacsonyabb státusú népességet tömörítố területe. A részletes rendezési tervhez* készült várostörténeti vizsgálatok igen alaposan tártják fel e városrész és a városrészen belüli különbözõ területi egységek kialakulásának körülményeit. E vizsgálódások azonban lényegében csak a városegyesítés koráig követik nyomon a Középsố-Józsefváros történetét. Való igaz egyfelól, hogy egy-egy városrész kialakulásának körülményei jelentốs hatással vannak annak út-, telek- és tömbhálózatára, beépítettségi viszonyaira. Másfelól azonban az is elmondható, hogy Budapest, de a Középsố-Józsefváros városfejlődésének zöme is a városegyesítés utáni idốszakra esik. A városegyesítés után épült az itt található lakások túlnyomó többsége, és még a korábbról itt maradt házak esetében is indokolt feltenni a kérdést: mi magyarázza azt, hogy ebben a városrészben ilyen szokatlan magas arányban maradtak fenn korábban épült, többnyire földszintes épületek? Könnyen belátható, hogy a Középsố-Józsefváros kialakulásának mikéntje valóban nagy jelentôséggel bír annak késốbbi fejlốdése szempontjából, de ettól a Középsô-Józsefváros a városegyesítés után még igen sokféle irányba fejlốdhetett volna. Ezért érdemesnek tủnik röviden összefoglalnunk a városrész késốbbi társadalmi fejlổdésére jelentốs befolyást gyakorló városépítési szabályozásra vonatkozó korábbi kutatásainkat.

Véleményünk szerint, a városegyesítés utáni építési szabályozás történetének ismeretében megállapítható, hogy a budapesti övezetek nem a szó klasszikus értelmében vett , természetes övezetek", hanem alapvetôen várostervezési produktumnak tekinthetốk. Nem utolsó sorban azonban éppen az övezetes szabályozás idézett elố, vagy erôsített fel egy sor, az övezetek fizikai és társadalmi értelemben vett heterogenitásának irányába mutató folyamatot. Látnunk kell ugyanis, hogy a városegyesítés utáni idốszakra jellemzô övezetes szabályozás, amelyik a város egész területét építési területnek tekinti, amelyik a város szerkezetét lényegében a város központjából kifelé haladva csökkenổ beépítési intenzitású, homogén övezetek rendszereként képzeli el, jelentốs mértékben önmaga megvalósulása ellen hatott.

$\mathrm{Az}$,,extenzív városfejlôdés" elkerülése érdekében a Közmunkatanács ugyanis egy sor intézkedést hozott. Ezek az intézkedések a külsố területeken igen magas telekminimumot, a város belsố övezeteiben pedig nagy telekszélességet és telekmélységet írtak elố, amelyek szinte lehetetlenné tették, hogy családi házak épüljenek a város akkori területén belül. Ez rendkívül magas

*A területre a Józsefvárosi Önkormányzat megbízásából a VÁTI munkatársai, Perczel Anna vezetésével, részletes rendezési tervet dolgoztak ki. 
Tér és Társadalom 6. évf. 1992/3-4. 75-88. p.

laksứrúséget és egy házra jutó lakásszámot eredményezett. Jelentổs mértékben hozzájárult ahhoz is, hogy a város fốtvonalai és az ezekhez közeli telkek viszonylag gyorsan és viszonylag egységes stílusban épüljenek be. Mindez azonban az egyes övezetek heterogenitásának irányába hatott. Mivel az építési szabályzat Budapest akkori, a mainak csak mintegy harmadát kitevố területén 5-6 millió lakos elhelyezését tette volna lehetôvé, még a kor igen gyors lakásépítési üteme sem eredményezhette, hogy a belsỏ területek mellékutcáinak túlnyomó többsége, valamint a bérházasnak nyilvánított külsỏ építési övezetek bérházakkal épüljenek be. A fentiek eredményeként létrejött területeken hézagos beépítés vált jellemzôvé, ami Budapestet a ,,tûzfalak városává" tette. Sokkal fontosabb azonban számunkra az, hogy mindez az övezetek városszerkezeti mintaként való érvényesülésének ellenében hatott, amennyiben fokozta az egy-egy övezeten belüli fởútvonalak és egyéb utcák ház- és lakásállományának különbségét. Ezt a hatást erốsítették azok a rendelkezések is, amelyek egy-egy fôutvonal, ritkábban tér gyorsabb és egységesebb stílusban való kiépülése érdekében rövidebb-hosszabb távra adómentességet biztosítottak az itt építkezôknek. A Nagykörút esetében példál ez az új házak 15 évi teljes és 15 évi részleges adómentességét jelentette.

Ugyanebbe az irányba - az övezetek városszerkezeti mintaként való érvényesülése ellen hatott az is, hogy mivel az építési szabályzatok az egész várost építési területként kezelték, a nagyváros expanziója nem , klasszikus módon” zajlott le. Többemeletes bérházak mellett földszintes, esetenként falusias házak, üres, késôbb raktározás, garázsok, vagy ipar céljaira igénybe vett telkek maradtak meg.

A Közmunkatanács kisházellenes intézkedéseivel kapcsolatban igen valószínũnek tûnik, hogy ebben nemcsak az , extenzív városfejlődés” elleni harc igen magasztos - egyébként ma is idốrốl-idổre felmerülỏ és korántsem csak várostervezố ideológiákáltal motivált - szempontjai játszhattak szerepet. Ez a politika odavezetett, hogy Budapesten a családiház-építés aránya az elsố világháborúig igen alacsony és csökkenô tendenciájú volt, továbbá, hogy sorházak és kislakásos bérházak szinte egyáltalán nem épültek. Ez minden bizonnyal mindenekelốtt azzal magyarázható, hogy a magyarországi polgári fejlốdés megkésett és ellentmondásos jellege miatt nem voltak elég erôsek azok a rétegek, amelyek a bérházépítố földbirtokos- és pénzarisztokrácia érdekeivel szemben sikeresen tudták volna képviselni saját érdekeiket. A családiház-építésnek a városból való kiszorításában a földbirtokos arisztokrácia egyes csoportjai azért is érdekeltek voltak, mert ilymódon a várost körülvevổ területeken megemelkedett a telekár, és emelkedtek a parcellázások révén megszerezhetổ összegek. A családiház-építés jelentős része tehát ebben az idôszakban a város akkori területén kívülre szorult, a budapesti kisegzisztenciák pedig szû́k, körfolyosós bérházak szoba-konyhás lakásaiba kényszerültek.

A Budapesten a városegyesítés táján kialakult építési szabályozás persze az idốk során, részben az övezetek lehatárolása, részben az elốrások szigorúsága tekintetében, elég gyakran és sokat változott, a normatív városépítési szabályozás ezen módszere azonban még sokáig lényeges hatást gyakorolt a város szerkezetére.

Hosszú harcok után tehát végülis csak az I. világháború elốestéjén született meg a gyökeresen új építési szabályzat. Ez annyiban mindenképpen elörelépést jelentett, hogy míg a korábbi szabályozások elsôsorban a városkép esztétikai megjelenésére, a mindenáron való nagyvárosias jellegre koncentráltak, az 1914-es szabályzatban már a korábbiaknál sokkal határozottabb szociális és egészségügyi intézkedések is felfedezhetốk voltak. A bérházak esetében csökkent a 
Tér és Társadalom 6. évf. 1992/3-4. 75-88. p.

telek beépíthetôsége és növekedett az udvar minimális alapterülete, egyszersmind megjelent a hátsó épitési vonal fogalma, ami a keretes beépítés előfutárának tekinthetô. Javultak a kötelezổ utcai légtérarányok is, ami valamivel kevésbé zsúfolt beépítést tett lehetớvé. Témánk szempontjából legfontosabb következménye a szabályzatnak azonban az, hogy létrehozott egy új, családiházas övezetet.

Alig néhány hónappal késốbb azonban kitört az I. világháború, aminek következtében a lakásépítési tevékenység szinte teljesen megszûnt. A vesztes háború után a Monarchia felbomlott. Magyarország területe egyharmadára csökkent. Az elcsatolt területekrốl hatalmas tömegek érkeztek a fơvárosba, lakás híján sokan szükség-táborokba, vagy vagonokba kényszerültek költözni. Ez, valamint a két világháború közötti igen alacsony magyarországi gazdasági növekedési ütem, nagy szegénység és minimális lakásépítési kedv, az építési hatóságokat különféle engedményekre kényszerítette. A helyzet sem a budapesti kertvárosias városrészek kialakulásának, sem olyan, korábban már beépült városrészek átépülésének nem kedvezett, mint amilyen a Középsô-Józsefváros is volt.

Viszonylag keveset változtatott a Középsô-Józsefváros arculatán a két világháború közötti idốszak legerốsebb építési konjunktúrája, ami a 30-as évek második felére, a 40-es évek legelejére esett. E területen várostervezési szempontból a legjelentósebb változást az jelentette, hogy a két világháború között még mindig alkalmazott körülépített udvaros beépítést lassan újfajta, kedvezốbb beépítési mód váltotta fel. Már az 1914-es építési szabályzatban megjelent a hátsó építési vonal fogalma, aminek továbbfejlesztése az ún. csatlakozó-udvaros beépítés, amelyról rövidesen az ún. keretes beépítésre tértek át. Mindez a korábbinál jóval kedvezóbb légtérarányok kialakulását tette lehetôvé. Szociológiai szempontból azonban sokkal lényegesebb ennél, hogy az ilymódon épült bérházakban praktikusan megszưnt a lakók ugyanazon épületen belüli szegregáciojának kiváltó oka, az a hatalmas különbség, ami a korábban épült körfolyosós bérházak utcai és udvari lakásainak mérete, komfortja, stb. között mutatkozott.

A 30-as évek közepétôl érvényesülổ építési konjunktúra azonban mindenekelốtt a ,telepítéspolitikai" irányelvek és az azok érvényesítését elôsegító adómentességi rendeletek által preferált területeken jelentkezett. Túl késôn indult be, és túlságosan rövid volt ahhoz, hogy számottevổen megváltoztassa a Középsô-Józsefváros jellegét. Inkább csak néhány jól sikerült épületet vagy épületegyüttest hozott létre, például a Népszînház utcában, vagy a Köztársaság-téren. A beindult, de nem városfejlổési okok miatt megrekedt konjunktúrális folyamat azonban máig szembetuinoó bizonyítéka annak, hogy a Középsó-Józsefváros és az ezt körülvevố terület napjainkban tetôzō, fokozatos leromlása nem a nagyvárosi expanzió egyedül lehetséges eredménye, csak a városfejlổés egyik lehetséges alternativája volt. A világháború kitörése, majd a városés lakásgazdálkodás rendszerének 1945 utáni radikális megváltozása tulajdonképpen egy meglehetốsen késôn, de mégiscsak beindult városrehabilitációs folyamatot szakított meg.

A Középsố-Józsefváros térbeni-társadalmi szerkezetéról összegzésként tehát elmondható, hogy e terület uralkodó háztípusát a többemeletes, körfolyosós bérházak különféle típusai jelentik. Azonban - mivel ez a városrész nem körfolyosós bérházakkal épült be elsố ízben, hanem különbözô mértékben ugyan, de már a múlt század elsô évtizedeiben is beépült, zömében földszintes vagy egyemeletes épületekkel, és e területen sohasem volt elég konjunktúra ahhoz, hogy a városrész teljesen átépüljön, de a városrész átépülése mégiscsak megindult - a domináns többemeletes, körfolyosós bérház itt egyéb típusokkal is kiegészül. Így tehát napjainkban 
megragadható városszerkezetei egységek éppen azáltal válnak el egymástól, hogy a domináns típus mennyire egyeduralkodója az egyes területeknek. A vizsgált területen kétféle szegregációs minta figyelhetổ meg: részben a körfolyosós bérházak utcai és udvari frontjainak lakásai közötti státuskülönbségek, részben a különbözố háztípusok adott területen belüli keveredésének arányai szabályozzák a különbözố társadalmi, demográfiai és etnikai csoportok térbeni elkülönülését.

A Középsố-Józsefvárosra is oly jellemzố többemeletes körfolyosós bérházak uralkodóvá válását szociológiai értelemben az tette lehetổvé, hogy az egyes társadalmi osztályok közötti politikai és egzisztenciális különbségek Budapesten nem voltak olyan óriásiak, mint a keleteurópai nagyvárosokban - amelyekre ezért, a nagy létszámú szolgahad állandó jelenlététól eltekintve, a magas státusúak lakóhelyeinek éles térbeni elkülönülése volt jellemzô -, de a nyugat-európai állapotokhoz képest elég nagyok és elég merevek voltak ahhoz, hogy a társadalmi jellegũ különbségeket ne kelljen éles térbeni elkülönüléssel is szimbolizálni. A körfolyosós bérházak lakóinak heterogenitása valószínúleg már az I. világháború után csökkenni kezdett. A tömegközlekedés elterjedése, majd a motorizáció térhódítása mellett ez valószínúleg mindenekelốtt azzal magyarázható, hogy csökkentek a szociális távolságok és valamelyest enyhült a társadalmi hierarchia egyértelműsége, ugyanakkor fokozódott a társadalmi konfliktusok élessége. Mindezek következtében a magasabb státusú csoportok számára egyre növekedett annak fontossága, hogy „másságukat” térbeni elkülönüléssel is szimbolizálják, hogy e „,másság” jelentổsségét más városrészbe való elkülönüléssel fokozzák. A városrész hanyatlása tehát már az I. világháború táján megindult, de - mint ezt korábban már említettük - a 30-as évek második felében újabb, sajnos elég hamar elvetélt lehetôség adódott a hanyatlás megállítására.

$\mathrm{Az}$ I. világháború után beindult folyamat azonban lényegesen felgyorsult a város- és lakásgazdálkodás szocialista rendszerére való átállás következtében. Míg ugyanis az államosítások többnyire nem érintették a város peremterületeinek kisebb családi házait, a bérházakat államosították. A 40-es évek végén, az 50-es évek elején az e házakban lévỏ nagyobb lakások tekintélyes részébe még legalább egy családot költöztettek, és a lakást , társbérletesítették", illetve a régi lakókat különbözổ módszerekkel lakásuk leválasztására kényszerítették. A házak karbantartását és felújitását elhanyagolták, így azok állapota fokozatosan leromlott. Ezzel párhuzamosan fokozódott a magas státusú népesség eláramlása errổ a területrỏl. Ez elóbb fốleg a budai hegyvidék szintén államosított villalakásai felé történt. Az ezen a területen fekvổ villák többnyire a korábbi rendszer leggazdagabb családjainak tulajdonát képezték, most pedig a magát elsốsorban szociális érvekkel legitimáló állami lakáselosztási szisztéma - burkolt elosztási csatornáin keresztül — az új rendszerben leginkább privilegizáltakat juttatta itt lakáshoz. Aki viszont tehette, elköltözött a slumosodó bérházas területekrốl, hiszen itt új lakások nem épültek, még a régi épületek állapotának megốrzésére sem törekedtek. Jószerivel csak a korábban létrehozott értékek felélése folyt - és folyik ma is. A bürokratikus elosztási rendszerben kisebb privilégiumokkal rendelkezổ családok elsốsorban új lakótelepeken jutottak lakáshoz, míg az ilyen privilégiumokat nem élvezổk, de szerény saját ház építéséhez szükséges anyagiakkal és igyekezettel bírók, fốleg szakmunkások, felismerve, hogy a bürokratikus elosztási rendszer által belátható idổn belül nem juthatnak lakáshoz, valamelyik külsố kerületben családi ház építésébe kezdtek. A pesti bérházakban lakó értelmiségiek többsége - korábban már ismertetett okok 
Tér és Társadalom 6. évf. 1992/3-4. 75-88. p.

miatt - szintén az állami lakáselosztás keretein kívül próbált szerencsét. Õk a 70-es évek közepétól kezdve egyre gyorsuló ütemben ,,vonultak ki” a többnyire a budai hegyvidéken épüló, társasházi lakásokba.

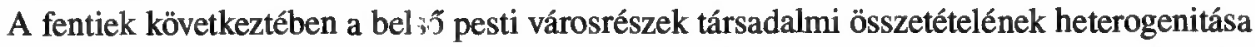
tehát nagymértékben csökkent. Ezt a folyamatot erôsítette fel, hogy az elköltözöttek helyére egyre alacsonyabb státusú családok költöztek be. Az erôsen centralizált, bürokratikus elosztási rendszer ugyanis fốleg itt juttatta lakáshoz azokat a családokat, akiknek telepi vagy leromlott külvárosi területeken fekvở lakásait megszüntette, de akiket új lakáshoz nem tudott vagy nem akart juttatni. Itt jutott lakáshoz azon nagy létszámú, sokgyerekes családok egy része is, akik számára a hatóságok nem tudtak az új lakótelepek többnyire kisméretú, nem elégséges szobaszámú lakásaiban megfelelō elhelyezést biztosítani. De itt jutottak lakáshoz például azok az alacsony jövedelmû́ családok vagy egyedülálló öregek is, akik nem lettek volna képesek az új lakással járỏ költségeket fedezni.

Egy leromló városrész életében a magasabb státusúak elköltözése és az alacsonyabb státusúak beáramlása mindig egymást kiegészítô, sốt egymást kölcsönösen felerốsítố folyamatokat jelentenek. Az általunk most tárgyalt bérházas városrẻsz slumosodásának folyamatában minốségileg ủj fejezet kezdơdött a cigány népesség tömeges beáramlásával. Cigányok ugyanis mindig laktak ezen a területen, de viszonylag kevesen és viszonylag lokalizáltan. Ezek a családok is a cigányság legfelsô rétegeit képezték, többnyire zenész cigányok voltak. A cigányok tömeges beáramlása csak valamikor az 1970-es évek közepén, a cigány- és szegénytelepek felszámolásával, majd a külsô kerületekben folyó ,,buldózeres" városfelújításokkal párhuzamosan indult meg és vált egy idố után öngerjesztố folyamattá.

Korábbi kutatásaink során különbözổ módszerekkel igyekeztünk bebizonyítani, hogy a szegény népesség és a hátrányos helyzetũ etnikai kisebbségek nagyvárosokon belüli lakóhelyi szegregációjának mintája alapvetốen eltér egymástól. A különbözở társadalmi csoportok szegregációjának esetében olyan tendencia érvényesült, hogy a magas státusúak inkább kevés, rendszerint nagy kiterjedésú és térben is összefüggố területre vagy területekre különülnek el, míg az alacsony státusúak rendszerint inkább több, kisebb területư és térben össze nem függô , ,mikroszegregátumban" tömörülnek. Ezzel szemben a hátrányos helyzetứ etnikai kisebbségek esetében inkább az a tendencia érvényesül, hogy az ilyen kisebbségek által szinte egyáltalán nem, illetve igen magas arányban lakott városrészek egyaránt igen nagy kiterjedésú, térben összefüggố területeket alkotnak.

A fenti összefüggés kimutatható Budapesten is az egyetlen nagy létszámú hátrányos helyzetứ kisebbség, a cigány népesség térbeni elkülönülésének esetében. Míg a belsô pesti kerületek egyre jobban slumosodó, zömében régi állami bérlakásokkal beépített területein a budapesti cigány népességnek csaknem a fele él, és ez az arány igen dinamikusan növekszik, a budai hegyvidék magas státusú, zömében új, magántulajdonú társasházakkal beépített részein szinte egyetlen cigány család sem lakik.

A budapesti cigány népesség térbeni elhelyezkedésének változásait - jobb adatok hiányában - az általános iskolák alsó tagozatos osztályaiba járó cigány gyerekekról összegyũjtött adatainkkal vagyunk kénytelenek bemutatni. Ezek szerint az 1971. és 1986. között eltelt 15 év alatt Budapesten pontosan megduplázódott, 1,2\%-ról 2,4\%-ra emelkedett a cigány tanulók aránya. Ezzel szemben a belsố pesti kerületekben (VI.-IX. ker.), ahol ez az arány már a 70-es évek 
Ladányi János : Gondolatok a Középső-Józsefváros rehabilitációjának társadalmi összefüggéseiröl (City rehabilitation in Central-Josephstadt in Budapest)

Tér és Társadalom 6. évf. 1992/3-4. 75-88. p.

legelején is 2,7\% volt, 1986-ra több mint megháromszorozódott, 8,3\%-ra emelkedett a cigány tanulók aránya. Ezek persze csak nagy területekre vonatkozó átlagadatok. Már a 80-as évek közepén, és éppen az általunk vizsgált Középsô-Józsefvárosban, voltak olyan kisebb lakóhelyi körzetek, ahol a cigány tanulók aránya $25 \%$-nál is magasabb volt, és mivel az iskolai szegregáció a lakóhelyi szegregáció erôsségének mértékét is felülmúlta, már akkor volt a városrésznek olyan általános iskolája (Erdélyi utcai általănos iskola), ahol a cigány tanulók arănya megközelítette az 50\%-ot.

Az 1991/92-es tanévben megismételtük a budapesti általános- és kisegítố iskolák alsó tagozataiba járó cigány gyerekek összeírását. Ezúttal azonban a pedagógusok által szegẻnynek, legalább egy munkanélküli gondviselổs családból származónak, mondott, továbbá azon gyerekek adatait is összeírtuk, akik nem Budapesten születtek vagy nem fốvárosi iskolába is jártak.

\section{TÁBLÁZAT}

A szegény, a cigány, a vidékról frissen felköltözött, valamint a legalább egy munkanélküli gondviselöjü tanulók aránya az általános és kisegító iskolások körében (\%)

(The proportion of those pupils in the primary schools and special schools for mentally retarded children whose parents are

poor, Roma, have recently moved to Budapest from the countryside, or have at least one unemployed parents, \%)

\begin{tabular}{lccc}
\hline & 1. Budapest & 2. VIII. ker. & $\begin{array}{c}\text { 3. Középsó́- } \\
\text { Józsefváros }\end{array}$ \\
\hline 4. Szegény & 10,2 & 18,4 & 24,5 \\
\hline 5. Cigány & 4,9 & 24,3 & 31,2 \\
\hline 6. Vidéki & 5,2 & 11,2 & 13,4 \\
\hline 7. Munkanélküli & 5,1 & 9,7 & 11,8 \\
\hline 1. Budapest & & \multicolumn{2}{l}{ 5. Roma } \\
2. Distríct VIII. & & $\begin{array}{l}\text { 6. Of rural origin } \\
\text { 3. Inner-Josephstadt }\end{array}$ &
\end{tabular}

Adataink tanúsága szerint a különbözổ városrészek státusát és stabilitását igen jól mérổ mutatóink mindegyike jóval magasabb értéket mutat a Józsefvárosban, mint a fôváros egészére. Figyelemre méltó azonban, hogy míg a szegények, a vidékiek (értsd: vidéken született és/vagy vidéki általános iskolába is járt alsó tagozatos gyermekek) és a munkanélküliek józsefvárosi arányai csak mintegy kétszer olyan magasak, mint a fơvárosi átlag, a cigány tanulók aránya esetében az eltérés már ötszörös. Mindez annak az általunk korábban már részletesen leírt tény- 
Ladányi János : Gondolatok a Középső-Józsefváros rehabilitációjának társadalmi összefüggéseiröl (City rehabilitation in Central-Josephstadt in Budapest)

Tér és Társadalom 6. évf. 1992/3-4. 75-88. p.

nek tulajdonítható, hogy Budapesten a cigányok lakóhelyi szegregációja jóval erôsebb és alapvetốen más mintát követ, mint az alacsony státusú népességé. Hasonló tendencia mutatható ki, ha a Józsefváros egészének adatait a vizsgálodásunk szũkebb területét képezõ Belsô-Józsefváros adatainak alakulásával is összevetjük. Megemlítendô azonban, hogy a cigányok aránya a kerületi átlagnál minden szempontból jóval kedvezốtlenebb helyzetũ Középsố-Józsefvárosban már lényegesen meghaladja a szegények arányát.

Korábban már bemutattuk, hogy milyen erôsen felülprezentált a cigány népesség a Józsefvárosban és különösen annak középsố területén. Meglepó állandóságot mutatnak viszont a szegények, a vidékiek és a munkanélküliek cigány népességen belüli arányai az általunk vizsgált különbözố területeken.

\section{TÁBLÁZAT}

A szegények, vidékról frissen felköltözöttek és a munkanélküliek cigány népességen belüli arányai (\%)

(Proportion of poor, of rural origin and unemployed in the Roma population, \%)

\begin{tabular}{|c|c|c|c|}
\hline & 1. Budapest & 2. VIII. ker. & $\begin{array}{l}\text { 3. Középsố- } \\
\text { Józsefváros }\end{array}$ \\
\hline 4. Cigány összesen (fổ) & 3948 & 670 & 100,0 \\
\hline 5. Ebból szegény & 50,7 & 41,3 & 43,0 \\
\hline vidéki & 25,9 & 25,8 & 26,0 \\
\hline szegény és vidéki & 14,5 & 11,2 & 11,3 \\
\hline munkanélküli & 24,7 & 22,5 & 22,8 \\
\hline
\end{tabular}

1. Budapest

2. District VIII.

3. Inner-Josephstadt

4. Roma total (head)

5. Of them poor

$6 . \quad$ of rural origin

7. poor and of rural origin

8. unemployed

A fenti táblázat látszik bizonyítani, hogy a Józsefvárosban, sốt ennek általunk vizsgált középsỡ részén is, a budapesti átlaghoz nagyon hasonló belsổ összetételư cigány népesség él. Nem mondható ugyanez el, ha a budapesti szegény népesség (pontosabban a korábban leírt módon mintánkba került gyermekcsoport) belsô összetételét vizsgáljuk meg. 


\section{TÁBLÁZAT}

A cigányok, vidékról frissen felköltözöttek és a munkanélküliek szegény népességen belüli arányai (\%)

(Proportion of Roma, of rural origin and unemployed in the poor population, \%)

\begin{tabular}{lcccc}
\hline & 1. Budapest & 2. VIII. ker. & $\begin{array}{c}\text { 3. Középsố- } \\
\text { Józsefváros }\end{array}$ \\
\hline 4. Szegény összesen (fố) & 8237 & 508 & 100,0 \\
\hline 5. Ebból cigány & 24,3 & 54,5 & 54,8 \\
\hline 6. & vidéki & 13,5 & 21,4 & 20,2 \\
\hline 7. & cigány és vidéki & 7,0 & 14,7 & 14,4 \\
\hline 8. & munkanélküli & 26,0 & 29,9 & 29,2 \\
\hline
\end{tabular}

1. Budapest

2. District VIII.

3. Inner-Josephstadt

4. Poor total (head)

5. Of them Roma

6. of rural origin

7. Roma and of nural origin

8. unemployed

Adataink szerint míg a budapesti szegényeknek csak kevesebb mint egynegyede, a józsefvárosi szegényeknek már több mint a fele cigány származású. Jelentôs, bár kisebb mértékư az eltérés a vidékról frissen felköltözöttek arányának tekintetében is, míg a vidéktốl frissen felköltözött cigányok józsefvárosi felülreprezentáltsága a szegények körében - a korábban elmondottaknak tulajdoníthatóan - lényegében megegyezik a cigány népesség józsefvárosi felülreprezentáltságának mértékével. A Középsố-Józsefváros adatai e csoportra vonatkozóan sem térnek lényegesen el a VIII. kerület adataiból. Újból hangsúlyoznunk kell azonban, hogy adataink nem a budapesti cigány és szegény népességre általában vonatkoznak, hanem csak az alsó tagozatos általános iskolás korú népességre. Ez a magasabb differenciális termékenység és az alacsonyabb átlagos életkor miatt viszonylag jó közelítést jelent a cigány népesség egészére vonatkozóan, a fenti okok, valamint a belsố városrészek rohamos elöregedése miatt viszont semmiképpen sem tekinthetố a szegény népesség egészére elfogadható közelítésnek. Az elóbb elmondottak értelmében a legszámottevốbb eltérést az okozta, hogy felvételünkból kimaradtak az idốs, és a gyermektelen szegény népesség csoportjai, amelyek pedig igen jelentôs kategóriáit képezik a belsố pesti városrészek szegény társadalmának.

Vizsgáljuk most meg részletesebb területi bontásban is az idáig felhasznált mutatók alakulását a Középsố-Józsefvárosban. Az elemzéshez elốször azokat a nagyobb, térben összefüggó területi egységeket használjuk fel, amelyeket a VÁTI munkatársai alakítottak ki az ott található épületek állapota, a lakások nagysága és komfortfokozata alapján. Tájékoztatásképpen közöljük még a VIII. kerület legmagasabb státusú része, a Belsô-Józsefváros (a VIII. kerületnek a József körúton belüli része) megfelelố adatait is. 
Ladányi János : Gondolatok a Középső-Józsefváros rehabilitációjának társadalmi összefüggéseiröl (City rehabilitation in Central-Josephstadt in Budapest)

Tér és Társadalom 6. évf. 1992/3-4. 75-88. p.

\section{TÁBLÁZAT}

A szegények és a vidékrốl frissen felköltözöttek cigány népességen belüli arányai

a VIII. kerület egyes területein (\%)

(Proportion of the poor and of those who have recently came from the countryside in the Roma population in certain parts of district VIII., \%)

\begin{tabular}{|c|c|c|c|c|c|c|}
\hline & \multicolumn{4}{|c|}{ 1. Középsô-Józsefváros } & \multirow{2}{*}{$\begin{array}{l}\text { 2. Belsō- } \\
\text { Józsefváros }\end{array}$} \\
\hline & & $\mathrm{A}$ & $\mathrm{B}$ & $\mathrm{C}$ & Összesen & \\
\hline & y összesen & 100,0 & 100,0 & 100,0 & 100,0 & 100,0 \\
\hline & 1 szegény & 30,9 & 43,5 & 55,3 & 43,0 & 34,0 \\
\hline 5. & vidéki & 33,3 & 25,0 & 19,7 & 26,0 & 26,6 \\
\hline 6. & szegény és vidéki & 11,1 & 13,0 & 9.2 & 11,3 & 11,3 \\
\hline
\end{tabular}

1. Central-Josephstadt

2. Inner-Josephstadt

3. Roma total

4. Of them poor

$5 . \quad$ of nural origin

6. poor and of rural origin

\section{TÁBLÁZAT}

A szegények és a vidékrôl frissen felköltözöttek szegény népességen belüli arányai a VIII. kerület egyes területein (\%)

(Proportion of the poor and of those who have recently came from the countryside in the poor population in certain parts of district VIII., \%)

\begin{tabular}{lcccccc}
\hline & \multicolumn{4}{c}{ 1. Középsố-Józsefváros } & 2. Belsố- \\
\cline { 2 - 6 } & $\mathrm{A}$ & $\mathrm{B}$ & $\mathrm{C}$ & Összesen & Józsefváros \\
\hline 3. Szegény összesen & 100,0 & 100,0 & 100,0 & 100,0 & 100,0 \\
\hline 4 4. Ebból cigány & 38,5 & 55,3 & 72,4 & 54,8 & 36,0 \\
\hline 5. & vidéki & 23,1 & 18,8 & 19,0 & 20,2 & 24,0 \\
\hline 6. & cigány és vidéki & 13,8 & 16,5 & 12,1 & 14,4 & 12,0 \\
\hline
\end{tabular}

1. Central-Josephstadt

2. Inner-Josephstadt

3. Poor total

4. Of them Roma

5 . of rural origin

6. poor and of rural origin

Az adatok tanúsága szerint a Középsố-Józsefváros itt elemzett különbözô területei mind a cigány, mind pedig a szegény népesség belsô összetétele tekintetében jelentôsen eltérnek egy- 
mástól. Az épület- és lakásállomány szempontjából legmagasabb státusú területen (A), a Rákóczi út-Fiumei út-Népszínház utca által határolt háromszögben, a József körút valamint a Baross utca menti, Horváth Mihály tér mögötti tömbjeiben nemcsak a cigányok és szegények arányai alacsonyabbak, de alacsonyabb a szegények cigányokon, és a cigányok szegényeken belüli aránya is. Ezen mutatók szempontjából is középsố helyzetet foglalnak el a KözépsốJózsefváros belsejében lévố tömbök (B), míg az épület-, lakásállomány, valamint a cigány és szegény népesség arányai szempontjából is legalacsonyabb státusúnak a Középsố-Józsefváros külsố, Erdélyi utca-Mátyás tér-Koszorú utca-Baross utca-Fiumei út által határolt része (C) tekinthetố. A Középsô-Józsefváros legmagasabb státusú térségének (A) státusa lényegében megegyezik a VIII. kerület legjobbnak tartott területével, a Belsố-Józsefvároséval.

Mint korábban már említettük, az 1986/87-es tanévben a mostanihoz hasonlóan egyszer már összeirrtuk a cigány tanulók adatait. Ezért módunk van arra, hogy felmérjük a cigány tanulók arányainak elmúlt öt év alatti változását az általunk vizsgált területen.

\section{TÁBLÁZAT}

A cigány tanulók megoszlása a Középsó-Józsefváros különbözổ státusú területein

(Distibution of Roma pupils in different parts

of district VIII.)

\begin{tabular}{ccccc}
\hline & A & B & C & 1. Összesen \\
\hline $1986 / 87$ & 32,1 & 33,8 & 34,1 & 100,0 \\
\hline $1991 / 92$ & 30,6 & 40,7 & 28,7 & 100,0 \\
\hline
\end{tabular}

1. Total

Az adatok tanúsága szerint a cigány tanulók aránya a vizsgált idôszakban a Középsô-Józsefváros legmagasabb státusú területén valamelyest, a legalacsonyabb státusú területen ennél valamivel nagyobb arányban csökkent, ugyanakkor a közepes státusú területen viszont számottevõen emelkedett. Ehhez hozzátehetjük, hogy míg az 1986/87-es tanévben a vizsgált három területen még lényegében megegyezổ számú cigány tanuló lakott, 1991/92-ben már egyértelmưen a B-vel jelölt területen volt a legmagasabb a cigány tanulók száma.

Mindezek az adatok azonban egyben azt is mutatják, hogy a legszegényebb, munkanélküli népességnek az ország leginkább válság sújtotta területeiról történó feláramlása még éppen csak elkezdôdött, és hogy a felköltözốk még többnyire csalảd vagy legalábbis gyermekek nélkül érkeznek. A Középsō-Józsefvároson belül kialakított kisebb területek közötti mérsékelt különbségek magyarázata másrészt feltehetốleg az, hogy még az általunk itt elemzett kisebb területek is viszonylag heterogénnek tekinthetôk, finomabb folyamatok megragadására ezért kevéssé alkalmasak. De véleményünk szerint ez arra is felhívja a figyelmet, hogy a várostervezônek ebben a térségben igen óvatosnak kell lennie a várostervezés szempontjából többé-kevésbé homogénnek kezelhetổ területek kialakításával, hiszen e területen az épített környezet és a lakók 
Tér és Társadalom 6. évf. 1992/3-4. 75-88. p.

társadalmi összetétele szempontjából leglényegesebb státuskülönbségek egyrészt a körfolyosós bérházak utcai és udvari frontjai között húzódnak, másrészt pedig a különbözổ idôszakokban épített földszintes, egy- és többemeletes háztípusok adott területen való keveredési arányainak megfelelốen alakulnak. Mindezek miatt véleményem szerint a várostervezônek ezen a területen inkább egy-egy épületben, utcaszakaszban, legfeljebb háztömbben, mint nagyobb összefüggó területekben érdemes gondolkodnia. Nagyléptékũ beavatkozásról egyébként azért sincs értelme töprengeni, mert igen nehezen képzelhetô el, hogy a jelenlegi gazdasági helyzetben belátható idổn belül pénz lenne nagyszabású várostervezôi beavatkozásra. Inkább a még menthetổ mentésére érdemes koncentrálni, továbbá olyan kisebb rehabilitációs projektekkel lehet kísérletezni, amelyek következtében legalább a rehabilitáció közvetlen környezetében megindul a terület felértékelôdése.

A Józsefváros, illetve a leromló belsõ pesti városrészek problémája egyébként véleményem szerint aligha kezelhetõ csupán a helyi önkormányzatok csekély mobilizálható pénzeszközeiból. Mint láttuk, nem egyszerúen kerületi, hanem budapesti, sốt országos problémák jelennek meg ezen a területen halmozott formában.

A kialakulófélben lévô, nagy kiterjedésú, alacsony státusú etnikai gettó teljesen új jelenség Budapesten. Létrejöttének ténye különösen akkor elgondolkodtató, ha figyelembe vesszük, hogy a budapesti cigányok aránya ma csak töredéke az észak-amerikai nagyvárosok többségében élổ etnikai kisebbségek arányának. Magyarországon ma körülbelül 400-450 ezer cigány él. Feltéve, hogy ez a népesség egytôl-egyig a fổvárosba költözne (ami a cigányok által magas arányban lakott területek munkanélküliségét, az életkörülmények rohamos ellehetetlenülését figyelembe véve, sajnos nem teljesen képtelen feltételezés), Budapesten a cigányok aránya még mindig csak alig haladná meg a $20 \%$-ot. Chicagoban például $40 \%$-nál is magasabb a fekete bũrũek aránya, amihez még 35\% körüli spanyol anyanyelvũ népesség és számos más, igen népes etnikai kisebbség (kínaiak, vietnamiak, koreaiak, lengyelek, ukránok, stb.) adódik hozzá. Képzeljük el, ha 3,5 százalék körüli budapesti cigány népesség megjelenése ilyen elốrehaladott gettósodási folyamatot eredményez, ilyen mértékú szociális és etnikai feszültségeket vált ki, mi várható akkor, ha a cigány népesség fốvárosba áramlásának folyamata - mint ez igen valószínü - a közeljövốben nemcsak folytatódni, hanem még erõsödni is fog? Mi várható akkor, ha - mint ennek kezdetei már megfigyelhetốk - a fôvárosba áramló cigányok mellett még nagyszámú, nem cigány szegény népesség indul meg a fôváros felé, nem is beszélve most a határainkon túlról érkezổ különbözố menekülthullámok fôvárosra zúdulásáról? Mi várható akkor, ha - mint ez igen valószínũ - ezen menekült áradatok jelentốs része éppen a cigányok által úgyis magas arányban lakott területeken települ meg átmenetileg vagy tartósan?

E folyamatoknak a fơváros életére gyakorolt kedvezốtlen hatása persze nyilvánvalóan nem akadályozható meg városgazdálkodási és várostervezési eszközökkel, a kedvezốtlen hatások csökkentésére és kezelhetổ keretek között való tartására azért talán lehetôség van.

Véleményünk szerint a Középsô-Józsefvárosban kialakulófélben levố gettósodási folyamat várostervezôii-városigazgatási kezelésének a következổ három alternatívája lehet:

1. A már beindult folyamatokat ,,spontánnak" és ,,megváltoztathatatlannak" tekintve, további, még szabadabb teret lehet engedni az utóbbi két-három évtizedben a területen egyre erôteljesebben érvényesülổ tendenciáknak. Legfeljebb arra kell törekedni, hogy a városrész leginkább látható területein megfeleló mederbe legyen terelve a gettósodási folyamat. Ezen alternatíva 
Ladányi János : Gondolatok a Középsö-Józsefváros rehabilitációjának társadalmi összefüggéseiröl

(City rehabilitation in Central-Josephstadt in Budapest)

Tér és Társadalom 6. évf. 1992/3-4. 75-88. p.

megvalósulásának a legjobbak az esélyei. Ha nem sikerült megállítani a magasabb státusú népességnek a kerületbôl való eláramlását (a magasabb státusúak eláramlását gyorsította egyebek mellett az az intézkedés is, amely egy idổe leállította a bérlakások eladását), ha nem sikerül meggátolni a cigány népességnek a területre való beáramlását, ha rövid távú haszon reményében továbbra is engedélyezik a prostitúcióhoz kapcsolódó különbözổ üzletágaknak a területre való beáramlását (miközben az önkormányzatot érổ veszteségek sokszorosan haladják meg az ebból származó adóbevételekbốl adódó hasznot, hiszen a környék lakásainak piaci értéke így igen gyorsan csökken), valóban igen beszúkülnek a várostervezổ lehetôsségei. Igazodva a korszellemhez, ide is lehet tervezni egy ,vigalmi negyedet”, ami, ha egyáltalán megvalósul belớle valami, leginkább a nyugat-európai vagy észak-amerikai nagyvárosok China-town-jainak valamilyen közép-kelet-balkáni változata lesz. Gondolkodni lehet persze arról is - és ilyen törekvések, sajnos, valóban léteznek -, hogy e Gipsy-town körül most már igazán gyors ütemben leromló területeken hol kellene például , ,autós utcát", vagy valami hasonló agyrémet létesíteni, esetleg lebontani néhány tömböt, hogy oda a leginkább rászorultaknak olcsóbérú szociális lakásokat lehessen építeni, ami mindenhol a legjobb módszere egy városrész teljes tönkretételének.

A korábban beindult folyamatok folytatódásának tehát igen jók az esélyei, annak ellenére, hogy a városrész slumosodásának felgyorsulása - véleményünk szerint - egyáltalán nem spontán folyamatok miatt következett be. A városrész rohamos leromlását szerintünk az itt található lakások zömének államosítása, majd a szükséges felújításoknak egy egész emberöltổn keresztuil való elmaradása okozta. Az állami tulajdonú lakások által dominált területek leromlása - hasonlóan mindenfajta állami kezelésbe került tulajdon leromlásához - ugyanis a város csaknem minden pontján bekövetkezett. A város térbeni-társadalmi szerkezetét alapvetốen befolyásoló, nagy kiterjedésứ folyamatként ez azonban csak a belsổ pesti kerületekben játszódott le, hiszen az állami tulajdonba került bérházak túlnyomó többsége itt található meg.

A nagy kiterjedésú etnikai gettó kialakulása tehát egyáltalán nem látszik szükségszerú és megállíthatatlan folyamatnak. A folyamatot a leginkább leromlott területek rehabilitációjával lassítani lehet, sốt, kedvezó esetben lehetôség van a gettósodási trend megállítására vagy megfordítására is. Ez nem képzelhetổ el a fớvárosi és az érintett kerületi önkormányzatok átgondolt és egymással is összehangolt tevékenysége nélkül. A legelesettebbek számára szociális lakásokat és szubvencionált lakbéreket kellene kialakítani, és törekedni kellene olyan antiszegregációs lakáspolitikai intézkedések kidolgozására, amelyek legalább azt céloznák, hogy a cigányság által legnagyobb arányban lakott terülteken ne növekedjék tovább a cigányok aránya. Emellett a jelenlegi slumterület legnagyobb részén már ,,csupán” olyan körülmények megteremtését kellene megcélozni, amelyek mellett a magántốkének is megéri, hogy beáramoljon erre a területre. A nemzetközi tapasztalatok szerint egy-egy városrész megújulása gyakran azzal jár, hogy az ott lakó legszegényebbek kiszorulnak onnan. A különbözó cigány szervezetek képviselő̉inek ezért a rehabilitációs programok legelejétốl kezdve részt kellene venniük ezek kidolgozásában, lebonyolításában és ellenơrzésében, ügyelve arra, hogy a rehabilitáció mindenekelốtt a már ott lakók érdekeit szolgálja.

A Középsố-Józsefváros valódi (nem vigalmi-negyed jellegũ) rekonstrukciója a gettósodási folyamat várostervezổi-városigazgatási kezelésének további két alternatíváját veti fel: 
2. Kiindulva abból, hogy ebben a városrészben a legmagasabb Budapesten a cigány népesség aránya, hogy viszonylag kicsiny területen itt él a legnagyobb számban a hazai cigányságnak a középosztályosodás útján már elindult rétege, hogy ebben a városrészben vertek leginkább gyökeret a cigányság különbözố szervezetei, és a cigány szervezetek többségét tömörítố Roma Parlament székhelye is itt található, a városrész ökologiai rehabilitációjával kapcsolatban meg lehet fogalmazni egy olyan célkitũzést, hogy a Középsổ-Józsefváros váljon a magyarországi cigányság egyfajta oktatási, kulturális, politikai, stb. központjává. Kézenfekvổ e megoldás és viszonylag kedvezóek a feltételek is arra, hogy például cigány középiskola, cigány mưvelôdési központ, színház, stb. települjön ebbe a városrészbe, hogy ide települjenek azok a termelési és értékesítési magánvállal kozások és szövetkezetek, amelyek például a munkanélküliség által leginkább sújtott területeken maradt kihasználatlan munkaerô és a nagyvárosi cigányság körében meglévổ kereskedelmi tapasztalatok és a kedvezốbb értékesítési lehetổségek összehozását valósíthatnák meg. Mindez, megfelelổ iskolarendszerrel, szociális hálózattal és szociális lakáspolitikával párosulva, megfelelốbb életesélyeket teremtene a városrész igen nagyszámú cigány lakosságának.

3. Számos érv szól azonban az elổzổ pontban ismertetett alternatíva ellen. Ezek közül a legfontosabbnak az látszik, hogy amennyiben a fent említett intézmények és szociális lehetôségek többsége ilyen, viszonylag kicsiny és amúgy is cigányok által magas arányban benépesített városrészben koncentrálódik, igen nagy az esélye annak, hogy tovább folytatódjon, esetleg meggyorsuljon a cigány népességnek e városrészbe való beáramlása és a gettósodási folyamat tovább folytatódjon, sốt felgyorsuljon. Erốsen hátrányos helyzetủ etnikai kisebbségrốl lévén szó, további beáramlás és koncentrálódás nyilvánvalóan kedvezốtlen társadalmi folyamatokat indukál, ami a ,,pozitív diszkrimináció" eredményeit igen rövid idô alatt a visszájára fordíthatja. De még abban a nem nagyon valószínú esetben is, ha mindez nem következik be, féló, hogy csak késốbbi idốpontra tolódik el a gettósodási folyamat felerôsödése. A hátrányos helyzetứ etnikai kisebbségek sikeres, középosztályosodó tagjai ugyanis egy ideig úgy költöznek egyre jobb lakásokba, hogy a gettón belül változtatják lakóhelyüket. Bizonyos îdố után azonban mindenhol a világon, ahol ezt a kisebbségekkel szembeni diszkrimináció egyáltalán lehetôvé teszi, elköltöznek a gettóból. Amennyiben pedig nagyon magas az etnikai kisebbség aránya a területen és nagyon rossz állapotok vannak ott, nem lesz olyan társadalmi csoport, amely az így támadt ưrt betölthetné, hanem a gettósodási trend most már egyre gyorsuló ütemben tovább fog folytatódni.

Mindezek miatt véleményem szerint célszerúbb lenne a fent említett intézmények és szociális lehetốségek térben dekoncentrált megvalósítása. Az üres lakásoknak rászorulók részére történõ kiutalásával, a legrosszabb minőségũ lakások lebontásával, a leromlott lakások felújításával, semmiképpen sem alacsony komfortfokozatú, silány minôségú, hanem viszonylag jó minôségú, piacon kelendố új lakások építésével, stb. törekedni lehetne arra, hogy megálljon a legalacsonyabb státusú népességnek a területre való beáramlása. Utcánként, ha kell, blokkonként végiggondolt antiszegregációs lakáspolitikával lépéseket lehetne tenni a terület etnikai heterogenitásának fokozására. Az iskolai körzethatárok átrajzolódásával (az ezen a területen levô iskolák igen közel vannak egymáshoz) csökkenteni lehetne az iskolai szegregációt. Mindenképpen ügyelni kellene azonban arra, hogy a rehabilitáció semmiképpen se hozza hátrányos helyzetbe az ott lakó népességet, továbbá arra, hogy az ott élổ lakosság a program egész idốtartama alatt részt vehessen a célkitũzések kialakításában és a lebonyolítás ellenổrzésében. 


\section{CITY REHABILITATION IN CENTRAL-JOSEPHSTADT IN BUDAPEST}

\section{JÁNOS LADÁNYI}

The present study was written on the basis of the papers that were prepared by the author on the rehabilitation of Central-Josephstadt as contributions to a detailed urban plan.

In the first part of the study, the author gives a historical overview of the urban regulations influencing the development of this part of the city. As a summary of his historical argumentations, the author states that the beginning of the "slummification process" cannot be considered to be the direct consequence of the ecological position of this part of the city. In order to support the above statement he declares that speeded-up "slummification" was not caused by spontaneous tendencies, but rather by the nationalization of the majority of flats in this district as a first step, and then by neglecting the necessary reconstruction works for more than 50 years. Though the above tendencies were typical of other parts of the capital city, they took place as widespread processes fundamentally influencing the socio-spatial structure of the city only in the districts of Inner Pest, primarily because the decisive majority of the nationalized flats can be found in this part of Budapest.

After the historical overview, the author presents and analyzes his data on that part of the population in this area who are poor, gypsy, unemployed and migrated from the countryside only recently. These data are compared with those of the Central-Josephstadt as a whole, with some parts of this area, and with the averages of the whole capital city.

In the last part, the study deals with the possible alternatives handling the "slummification process" by means of urban planning and urban management, with the chances of their realization, and with their expected social consequences. 